\title{
Response of Native Aromatic and Medicinal Plant Species to Water Stress on Adaptive Green Roof Systems
}

\author{
Iro Kokkinou, Nikolaos Ntoulas, Panayiotis A. Nektarios ${ }^{1}$, \\ and Dimitra Varela \\ Laboratory of Floriculture and Landscape Architecture, Department of Crop \\ Science, Agricultural University of Athens, Iera Odos 75, Athens 118 55, \\ Greece
}

Additional index words. drought stress, leaf stomatal resistance, SPAD, deficit irrigation, substrate moisture

\begin{abstract}
The aim of this study was to determine the effects of different irrigation regimens on five native aromatic and medicinal species including Ballota acetabulosa (Greek horehound), Helichrysum orientale (helichrysum), Melissa officinalis (lemon balm), Rosmarinus officinalis (rosemary), and Salvia fruticosa (Greek sage) when grown on adaptive green roof systems. The applied levels of irrigation were $100 \%$ (well-watered control), $75 \%, 50 \%, 25 \%$, and $0 \%$ (no irrigation) of the daily pan evaporation $\left(E_{\text {pan }}\right)$. Measurements included the in situ determination of substrate moisture, stomatal resistance, and soil plant analysis development (SPAD) values. It was found that Greek horehound, helichrysum, and rosemary can sustainably grow at an irrigation of $25 \%$ $E_{\text {pan }}$, whereas Greek sage and lemon balm require an irrigation of at least $50 \% \mathrm{E}_{\text {pan }}$ for sustainable growth in shallow adaptive green roof systems.
\end{abstract}

The rapid development of contemporary cities has caused dramatic changes in urban landscape and climate. Increased population density, particularly in city centers, in conjunction with the sealing of major land portions through building and construction work, have resulted in the lack of urban open and green spaces (Ferguson, 1998). All the above have negatively affected the urban microclimate, including air and water quality, and have caused environmental deterioration, thus endangering public health, while also degrading life quality along with the comfort and wellbeing of the inhabitants.

Green roofs provide contemporary technical solutions that could increase urban green spaces and contribute to the amelioration of environmental problems. Roofs and recessed penthouses cover a large area of the built urban spaces, especially in city areas

Received for publication 18 Nov. 2015. Accepted for publication 23 Mar. 2016.

This article is part of an MSc thesis submitted to the Department of Crop Science, Agricultural University of Athens, by Iro Kokkinou.

The project (Urban BioRoof) with the code number 12 CHN136 was funded by the Hellenic General Secretariat of Research and Technology under the Operational Programme "Competitiveness and Entrepreneurship" (EPAN II) and by the Regional Operational Programmes of the five Regions of transitional support, under the Action "Bilateral Research and Technological Cooperation between Greece and China 2012-2014."

The mention of a trade mark, proprietary product or vendor does not imply endorsement by the authors nor does it imply approval to the exclusion of other products that may also be suitable.

${ }^{1}$ Corresponding author. E-mail: pan@aua.gr. which are characterized by dense building networks. Several researchers have reported, or forecasted through modeling, that green roofs could decrease ambient temperature (cooling) during summer, increase relative humidity, reduce infrared, and diffuse radiation (Kumar and Kaushik, 2005; Simmons et al., 2008). Further advantages resulting from green roof implementation include oxygen production by photosynthesis (Getter et al., 2009), building energy savings for summer cooling (Kotsiris et al., 2012a), reduction of air pollutants (Czemiel Berndtsson, 2010; Rowe, 2011), regulation of stormwater runoff and minimization of flooding events (Czemiel Berndtsson, 2010; Fioretti et al., 2010; Oberndorfer et al., 2007; Simmons et al., 2008; Van Woert et al., 2005), and amelioration of urban heat island effect (Akbari et al., 2001; Getter and Rowe, 2006).

Thus, the general concept is the development of a green roof networking which can contribute to the improvement of the microclimate in multiple ways if green roofs are largely implemented in urban areas. Therefore, it is necessary to seek ways to construct them on top of existing buildings. Because of the minimum load-bearing capacity of most existing buildings, either extensive or adaptive green roofs (Nektarios et al., 2011, 2015; Ntoulas et al., 2012, 2013b) are appropriate for green roof implementation. Extensive green roofs are characterized by minimal substrate depths $(2-15 \mathrm{~cm})$ that result in loads between 20 to $120 \mathrm{~kg} \cdot \mathrm{m}^{-2}$. They are usually planted with succulent plants and require low or no maintenance (FLL, 2008). Adaptive green roof systems also use minimal substrate depth $(5-15 \mathrm{~cm})$, but are planted with various plant types such as aromatic and medicinal plants, turfgrasses, and groundcovers. In contrast with the extensive green roofs, the adaptive ones are accessible and require minimal irrigation inputs (Kotsiris et al., 2013; Ntoulas et al., 2012, 2013a, 2013b; Ntoulas and Nektarios, 2015). Both extensive and adaptive green roofs require the use of plant species that have adequate water-stress tolerance and are capable of growing in shallow substrate depths.

Plant species for either extensive or adaptive green roof systems should be preferably native and adapted to local environmental conditions. Dimopoulos et al. (2013) reported that the prolific flora of Greece consists of 5752 kinds of plant species (1278 endemic), of which many of them are herbs, aromatics, and pharmaceuticals that could be considered appropriate for sustainable growth on Mediterranean green roof systems in conjunction with minimal water inputs (Benvenuti and Bacci, 2010; Kotsiris et al., 2012b, 2013; Nektarios et al., 2011, 2015; Papafotiou et al., 2013; Paraskevopoulou et al., 2015; Tassoula et al., 2015).

The aim of the present study is to determine the irrigation threshold based on $\mathrm{E}_{\text {pan }}$ for five medicinal and aromatic plant species. The findings of this research may be valuable in selecting the most appropriate plants for Mediterranean green roof systems and in predicting the minimal required irrigation inputs for sustainable growth.

\section{Materials and Methods}

\section{Experimental setup}

The study was conducted on the roof of the campus restaurant at the Agricultural University of Athens (lat. $37^{\circ} 59^{\prime}$, long. $23^{\circ} 42^{\prime}, 36$ a.s.1.). The study period was between 23 July and 9 Sept. 2013 and it was conducted on 90 rectangular plastic containers with internal dimensions of $24 \mathrm{~cm} \times 24 \mathrm{~cm} \times 11 \mathrm{~cm}$. Within each container, a green roof system was simulated containing three layers having a total height of $2.7 \mathrm{~cm}$. The layers were placed in the following order initiating from the bottom of the containers toward the substrate: a) protection and moisture retention fabric (VLS 300; Diadem, Landco Ltd., Athens, Greece); b) undulated drainage (Diadrain 25H; Diadem, Landco Ltd.); and c) geotextile (VLF 150; Diadem, Landco Ltd.). As a growing substrate, a mix of pumice $(75 \% \mathrm{v} / \mathrm{v})$, clinoptilolite zeolite $(10 \% \mathrm{v} / \mathrm{v})$, peat $(8 \% \mathrm{v} / \mathrm{v})$, and compost from garden waste and dairy manure ( $7 \% \mathrm{v} / \mathrm{v})$ was placed on top of the geotextile at a depth of $8 \mathrm{~cm}$. The physical and chemical properties of the substrate are listed in Table 1 whereas the mechanical analysis and the water-retention capacity are listed in Table 2.

\section{Plant material}

The study included five species of native aromatic and medicinal plants of the Greek flora: B. acetabulosa (Greek horehound, 15 plants), H. orientale (helichrysum, 20 plants), $M$. officinalis (lemon balm, 15 plants), $R$. officinalis (rosemary, 20 plants), and $S$. fruticosa 
(Greek sage, 20 plants). Differences in the number of plants used were due to plant losses during their propagation from the wild. The plants were collected from Euboea (lemon balm), Attiki (rosemary), the islands of Kythnos (Greek horehound), and Crete (helichrysum and Greek sage). They were collected as cuttings from their natural habitat in May 2012 except for lemon balm that was collected in June 2012. Plant propagation was performed under mist for 5-8 d depending on the species at the Laboratory of Floriculture and Landscape Architecture of the Agricultural University of Athens. After their propagation, the plants were acclimatized for 2 weeks and then transferred to the experimental roof in $10-\mathrm{cm}$ diameter pots where they grew for 1 year.

On 16 June 2013, a single plant was transplanted into each experimental container that was equipped with green roof layers and substrate. At the initiation of the study, the heights of the plants were similar between replications of each species. More specifically, the Greek horehound had a height of $19.2 \mathrm{~cm}$ $( \pm 1.2 \mathrm{SE})$, helichrysum $14.2 \mathrm{~cm}( \pm 0.5 \mathrm{SE})$, lemon balm $21.2 \mathrm{~cm}( \pm 0.9 \mathrm{SE})$, rosemary $17.8 \mathrm{~cm}( \pm 1.1 \mathrm{SE})$, and Greek sage $25.5 \mathrm{~cm}$ $( \pm 1.8 \mathrm{SE})$. After transplanting, all containers were placed on the building roof under mild shade for $20 \mathrm{~d}$ and irrigation was provided as needed. On 5 July 2013, the plants were transferred to full sun. On 23 July 2013, irrigation was applied to saturation to produce uniform wet conditions in between treatments at the initiation of water-stress period.

The water-stress period lasted from 24 July to 9 Sept. 2013. During the water-stress period, five different irrigation regimens were implemented based on daily evaporation $\left(E_{p a n}\right)$, which was determined by a Class A evaporation pan. For each plant species, irrigation was applied daily either at $100 \%$ $\mathrm{E}_{\text {pan }}$ (well-watered control) or at $75 \%, 50 \%$, $25 \%$ (as deficit irrigation treatments), or $0 \%$ (drought) of $\mathrm{E}_{\text {pan }}$. All treatments were watered by hand at $0800 \mathrm{HR}$ using a watering can equipped with perforated nozzle to ensure uniformity.

\section{Experimental design, treatments, and statistical analysis}

The plot arrangement followed a completely randomized design with helichrysum, rosemary, and Greek sage having four replications and Greek horehound and lemon balm having three replications per treatment. To determine the irrigation threshold for sustainable growth of each of the five plant species, a comparison between the five different irrigation regimens $(100 \%, 75 \%, 50 \%$, $25 \%$, and $0 \%$ of daily $\mathrm{E}_{\mathrm{pan}}$ ) was performed for each plant species independently. Oneway analysis of variance was performed on the collected data employing the statistical analysis software Statgraphics Centurion, version 15.2.11 (Statpoint Technologies Inc., Warrenton, VA). Our main research interest focused on plant response based on the imposed irrigation regimen on each sampling date. Treatment means for all statistical analyses were separated using the Fisher's protected least significant difference at a $0.05 P$ level $(P<0.05)$.

\section{Measurements}

Substrate moisture content. During the water-stress period, substrate moisture content

Table 1. Physical and chemical properties of the substrate that comprised of pumice $(75 \% \mathrm{v} / \mathrm{v})$, clinoptilolite zeolite $(10 \% \mathrm{v} / \mathrm{v})$, peat $(8 \% \mathrm{v} / \mathrm{v})$, and compost from garden waste and dairy manure $(7 \% \mathrm{v} / \mathrm{v})$. Values represent the mean values of three replications $( \pm \mathrm{SE})$.

\begin{tabular}{lcr}
\hline Measurement & Unit & Value $( \pm \mathrm{SE})$ \\
\hline $\mathrm{pH}$ & & $8.36( \pm 0.02)$ \\
Electrical conductivity & $\mu \mathrm{S} \cdot \mathrm{cm}^{-1}$ & $262.7( \pm 7.80)$ \\
Weight at saturation & $\mathrm{g} \cdot \mathrm{cm}^{-3}$ & $1.30( \pm 0.05)$ \\
Weight at maximum field capacity & $\mathrm{g} \cdot \mathrm{cm}^{-3}$ & $1.20( \pm 0.03)$ \\
Dry weight & $\mathrm{g} \cdot \mathrm{cm}^{-3}$ & $0.85( \pm 0.03)$ \\
Total porosity & $\%$ & $44.4( \pm 2.30)$ \\
Hydraulic conductivity & $\mathrm{mm} \cdot \mathrm{min}^{-1}$ & $7.56( \pm 0.53)$ \\
\hline
\end{tabular}

Table 2. Mechanical analysis and water-retention capacity of the green roof substrate that comprised of pumice $(75 \% \mathrm{v} / \mathrm{v})$, clinoptilolite zeolite $(10 \% \mathrm{v} / \mathrm{v})$, peat $(8 \% \mathrm{v} / \mathrm{v})$, and compost from garden waste and dairy manure $(7 \% \mathrm{v} / \mathrm{v})$. Values represent the mean values of three replications $( \pm \mathrm{SE})$.

\begin{tabular}{|c|c|c|c|}
\hline \multicolumn{2}{|c|}{ Mechanical analysis } & \multicolumn{2}{|c|}{ Water-retention capacity } \\
\hline$\overline{\text { Particle size }(\mathrm{mm})}$ & Retained $(\% \mathrm{w} / \mathrm{w})$ & $\overline{\text { Suction }(\mathrm{cm})}$ & Water content $(\% \mathrm{v} / \mathrm{v})$ \\
\hline$>10 \mathrm{~mm}$ & $3.77( \pm 0.47)$ & 0 & $32.5(3.54)$ \\
\hline $10-8 \mathrm{~mm}$ & $1.54( \pm 0.26)$ & 10 & $29.4( \pm 1.57)$ \\
\hline $8-4 \mathrm{~mm}$ & $19.30( \pm 1.01)$ & 20 & $27.9( \pm 3.15)$ \\
\hline $4-2 \mathrm{~mm}$ & $28.08( \pm 0.33)$ & 30 & $26.8( \pm 1.44)$ \\
\hline $2-1 \mathrm{~mm}$ & $13.28( \pm 0.39)$ & 40 & $26.1( \pm 0.65)$ \\
\hline $1-0.5 \mathrm{~mm}$ & $8.69( \pm 0.36)$ & 50 & $25.7( \pm 1.95)$ \\
\hline $0.5-0.25 \mathrm{~mm}$ & $6.61( \pm 0.30)$ & 60 & $25.2( \pm 2.16)$ \\
\hline $0.25-0.1 \mathrm{~mm}$ & $7.28( \pm 0.40)$ & 70 & $24.3( \pm 0.72)$ \\
\hline $0.1-0.05 \mathrm{~mm}$ & $4.76( \pm 0.23)$ & 80 & $23.1( \pm 0.62)$ \\
\hline$<0.05 \mathrm{~mm}$ & $6.69( \pm 0.95)$ & 90 & $22.6( \pm 1.23)$ \\
\hline
\end{tabular}
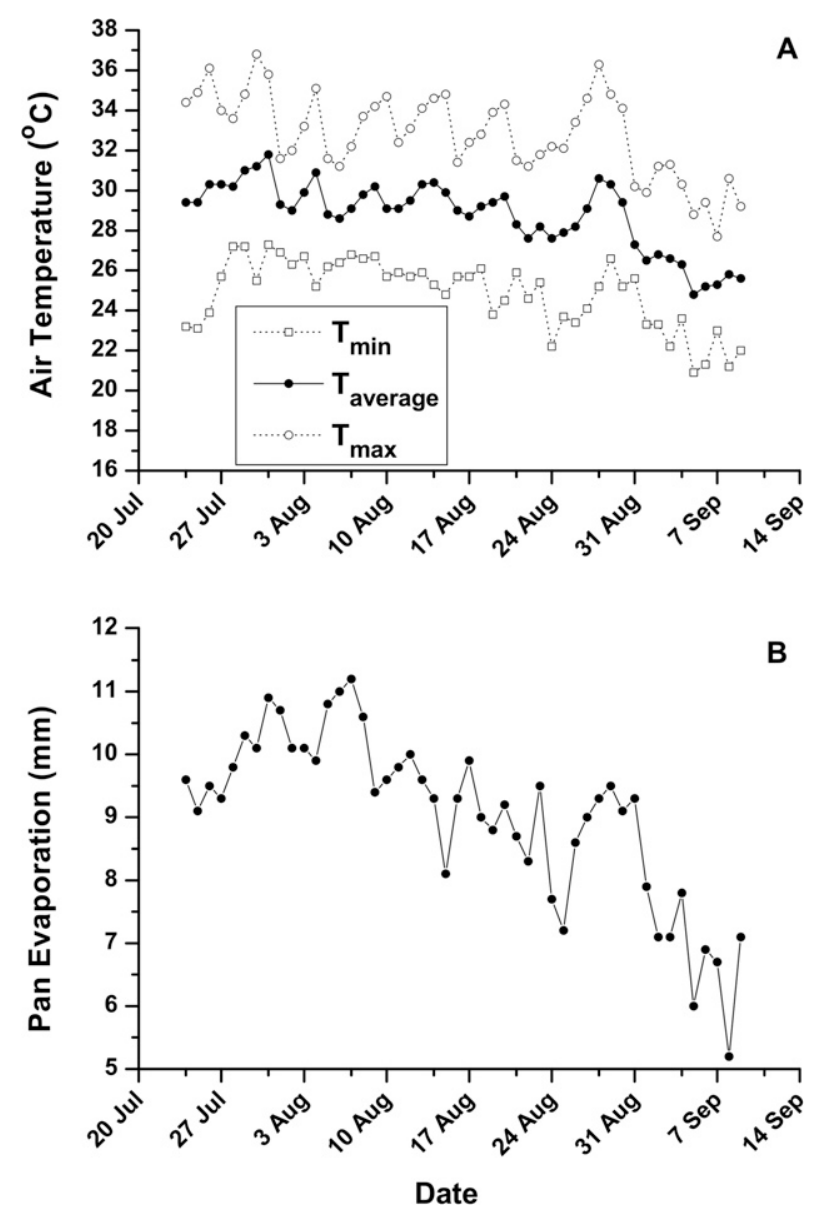

Fig. 1. (A) Daily maximum, minimum, and average air temperatures and (B) Class A-pan evaporation for the experimental period (24 July to 9 Sept. 2013). No rainfall occurred during the study period. 


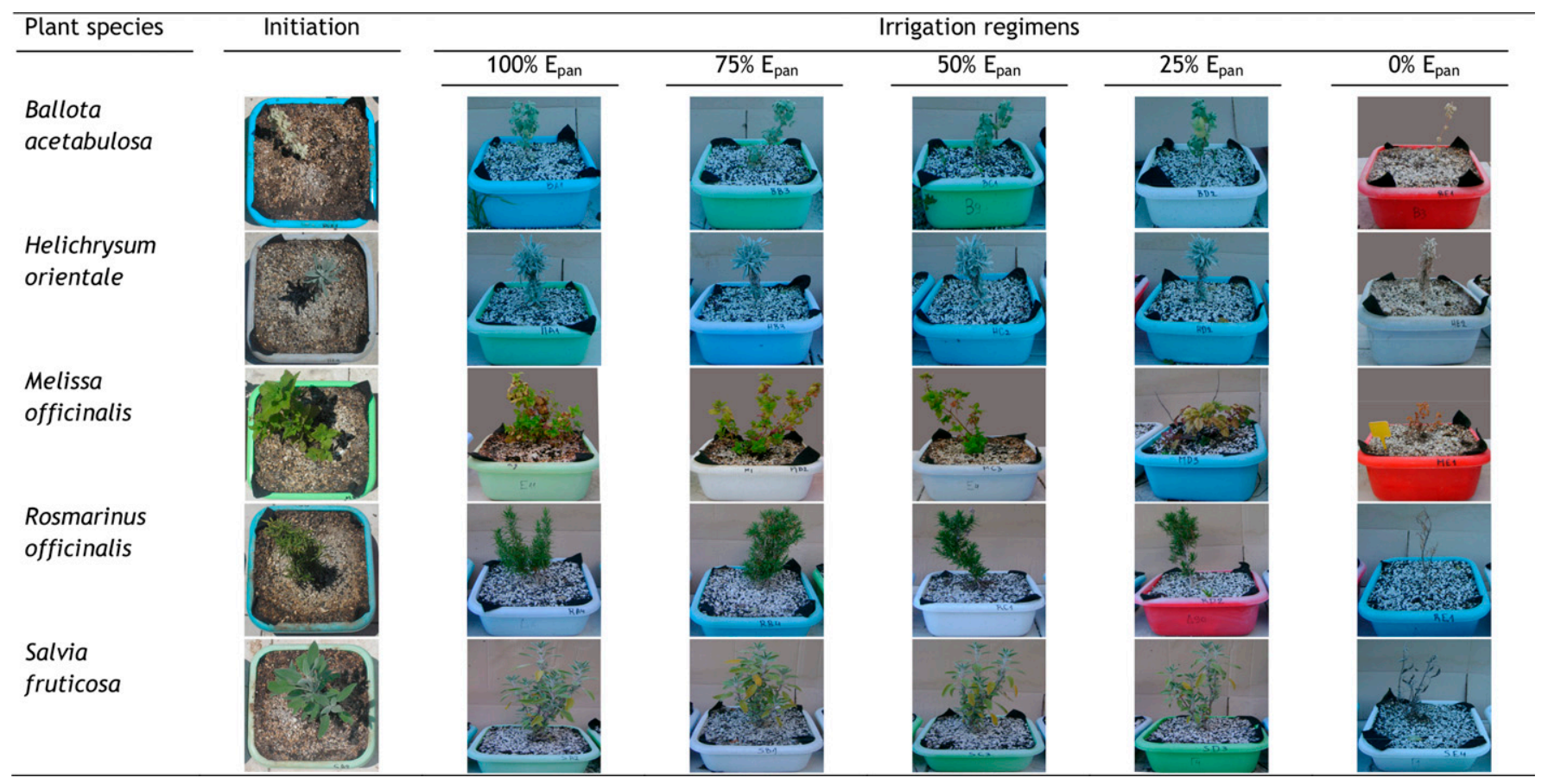

Fig. 2. Photographic representation of the five plant species at the initiation (22 July 2013) and at the end of the study (10 Sept. 2013 ) after the imposition of different irrigation regimens $\left[100 \%, 75 \%, 50 \%, 25 \%\right.$, and $0 \%$ of daily pan evaporation $\left.\left(\mathrm{E}_{\mathrm{pan}}\right)\right]$.

was determined every $3 \mathrm{~d}$ at $1500 \mathrm{HR}$, with the use of a WET-2 (Delta-T Devices, Cambridge, UK) frequency domain dielectric soil moisture sensor having rods of $65 \mathrm{~mm}$ in length, and spaced $45 \mathrm{~mm}$ apart. The sensor measured moisture content from a cylindrical substrate volume of $\approx 500 \mathrm{~mL}$, and it was connected to a HH2 handheld moisture meter (Delta-T Devices). The sensor was calibrated for the specific substrate used in the study according to Kargas et al. (2013).

$S P A D$. SPAD provides arbitrary values that indicate the green color of the leaves and its values have been correlated to plant chlorophyll content (Loh et al., 2002). SPAD measurements were performed every $3 \mathrm{~d}$ at around $1330 \mathrm{HR}$ with a handheld SPAD meter (SPAD502 Chlorophyll meter; Konica Minolta, Japan). For each measurement, the youngest of fully developed leaves were selected.

Leaf stomatal resistance. Leaf stomatal resistance measurements were performed every $3 \mathrm{~d}$ at noon, using an AP4 diffusion porometer (Delta-T Devices). Measurements were made on the abaxial side of young, fully expanded leaves.

Meteorological data. The ambient maximum, minimum, and average temperatures were recorded by the weather station of the National Observatory of Athens at the Gazi region, which is located $885 \mathrm{~m}$ from the experimental site. It should be emphasized at this point that during the water-stress period, no rainfall occurred (Fig. 1).

\section{Results and Discussion}

Ballota acetabulosa. In the beginning of the study, the substrate moisture content in

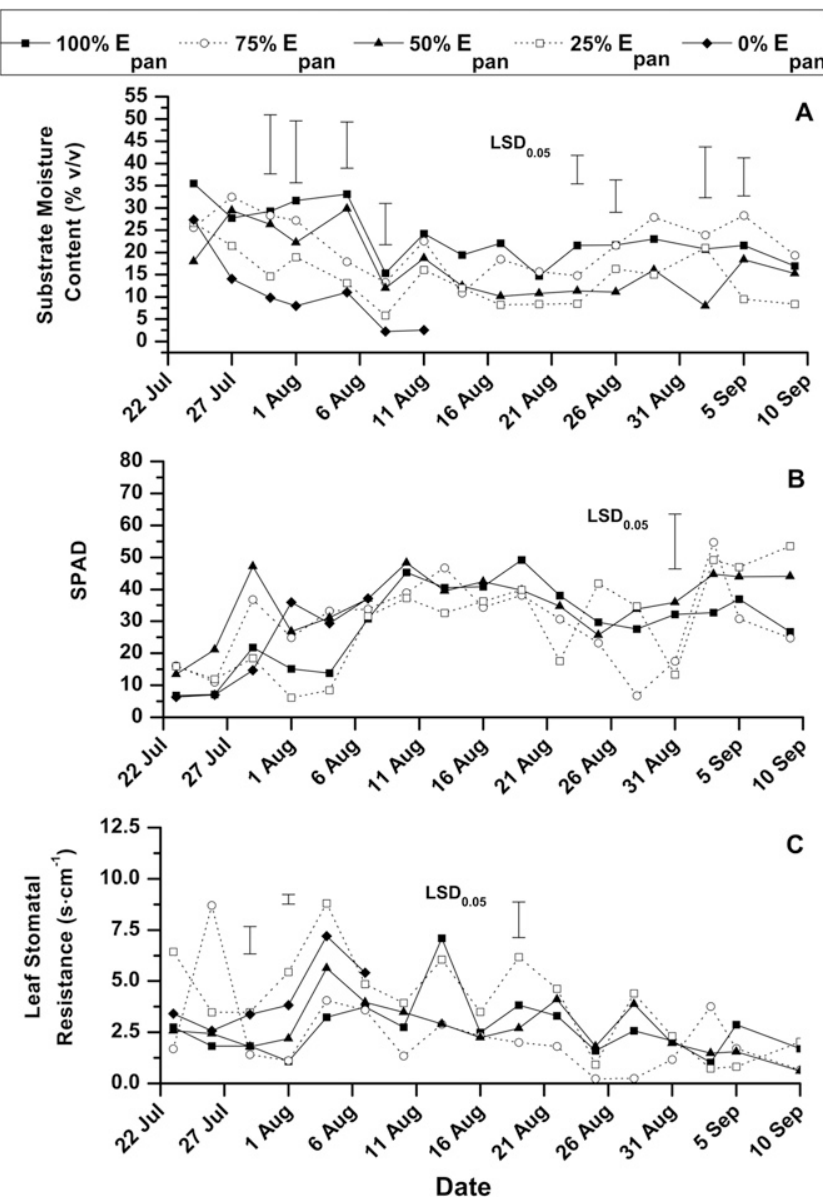

Fig. 3. (A) Substrate moisture content (\% v/v), (B) soil plant analysis development (SPAD) values, and (C) leaf stomatal resistance $\left(\mathrm{s} \cdot \mathrm{cm}^{-1}\right)$ for Ballota acetabulosa under different irrigations regimens $[100 \%$, $75 \%, 50 \%, 25 \%$, and $0 \%$ of daily pan evaporation $\left.\left(\mathrm{E}_{\mathrm{pan}}\right)\right]$. Bars represent Fisher's least significant difference (LSD) at $P<0.05$. 
plots planted with Greek horehound plants was similar for $100 \%, 75 \%$, and $50 \%$ of $\mathrm{E}_{\mathrm{pan}}$ irrigation regimens. In contrast, irrigation regimens of $25 \%$ and $0 \% \mathrm{E}_{\mathrm{pan}}$ exhibited lower substrate moisture content compared with the remaining treatments (Fig. 3A). However, differences between $25 \%$ and $50 \%$, and $75 \%$ and $100 \%$ were negated after 11 Aug. 2013.

From macroscopic phenological observations, it was noticed that in Greek horehound plants, at $0 \%$ and $25 \% \mathrm{E}_{\text {pan }}$ irrigation regimen, the leaves turned yellow and some of the leaves dropped (Fig. 2). The nonirrigated plants $\left(0 \% \mathrm{E}_{\mathrm{pan}}\right)$ died after $20 \mathrm{~d}$, indicating that the reduced leaf area of Greek horehound in conjunction with its xerophytic morphological and physiological characteristics provided an excellent drought mechanism. The time interval of $20 \mathrm{~d}$ coincides with that reported by Bousselot et al. (2011) for the observed dying of herbaceous plants top growth when drought was imposed in greenhouse conditions.

SPAD results were similar for all treatments. At the initiation of the study, SPAD values were low because Greek horehound has a grey leaf color, which is attributable to the numerous hair found on both sides of the leaf (Fig. 3B).

Leaf stomatal resistance exhibited minimal differences between irrigation treatments, according to which the nonirrigated and the $25 \% \mathrm{E}_{\mathrm{pan}}$ treatment provided higher resistance values (Fig. 3C). The latter illustrates that the plants of $25 \%$ and $0 \% \mathrm{E}_{\mathrm{pan}}$ were more stressed compared with the other irrigation treatments. Nevertheless, the leaf stomatal resistance values were relatively low for all irrigation treatments and, thus, Greek horehound stomata did not close at the deficient irrigation regimens. This observation, in conjunction with the increased substrate moisture content, demonstrated that Greek horehound exhibited other substrate moisture-stress tolerance mechanisms. It must be noted that Greek horehound is a common herbaceous, xerophytic species found in abundance in southern and eastern Greece (Heywood and Richardson, 1990). The drought adaptation mechanisms of xerophytes involve small and thick leaves, with high specific dry weight, small volume of internal air space, a high percentage of palisade mesophyll tissue (Parkhurst and Loucks, 1972; Shields, 1950), and a layer of hairs.

Helichrysum orientale. Similar to Greek horehound, the moisture content in plots planted with helichrysum substrate increased in the irrigated compared with the nonirrigated plants (Fig. 4A). However, in this case, the $25 \% \mathrm{E}_{\mathrm{pan}}$ irrigation treatment provided similar moisture content compared with the other irrigation treatments during the first $15 \mathrm{~d}$ of the water-stress period. It was noticed that in the helichrysum plants irrigated at the low-irrigation regimen of $25 \% \mathrm{E}_{\mathrm{pan}}$ as well as the nonirrigated treatment $\left(0 \% \mathrm{E}_{\mathrm{pan}}\right)$, the leaves reduced their surface area either by reducing their size and/or by becoming twirled (Fig. 2). Helichrysum has been found to tolerate relatively mild water stress when grown under green roof conditions and irrigated to saturation
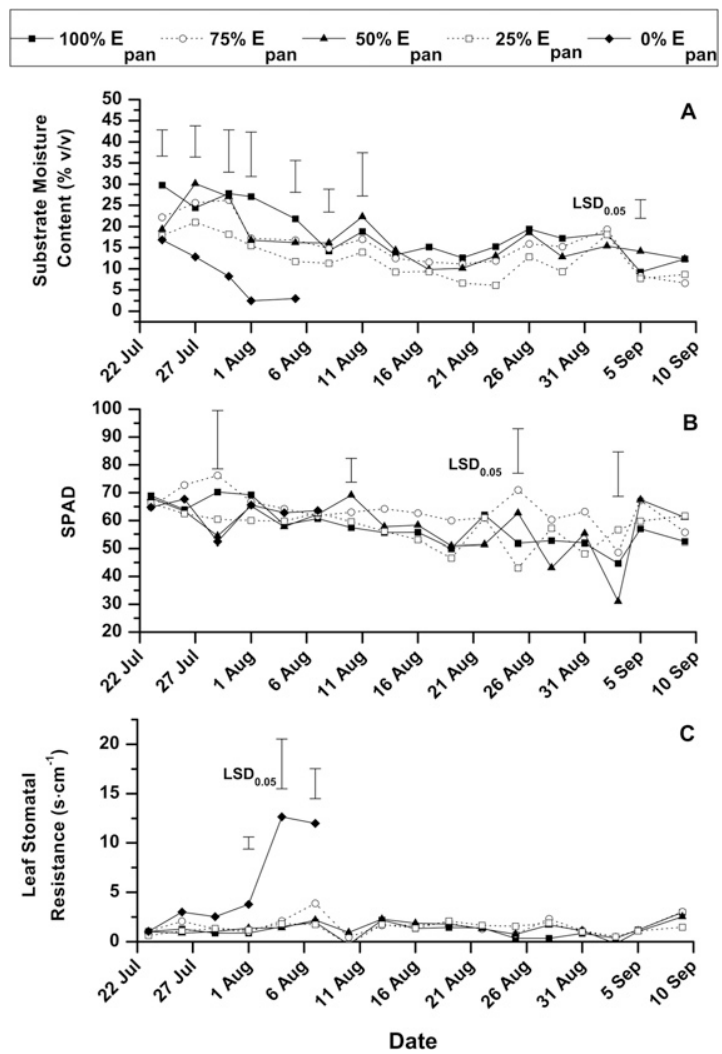

Fig. 4. (A) Substrate moisture content (\% v/v), (B) soil plant analysis development (SPAD) values, and (C) leaf stomatal resistance $\left(\mathrm{s} \cdot \mathrm{cm}^{-1}\right)$ for Helichrysum orientale under different irrigations regimens $[100 \%$, $75 \%, 50 \%, 25 \%$, and $0 \%$ of daily pan evaporation $\left.\left(\mathrm{E}_{\mathrm{pan}}\right)\right]$. Bars represent Fisher's least significant difference (LSD) at $P<0.05$.
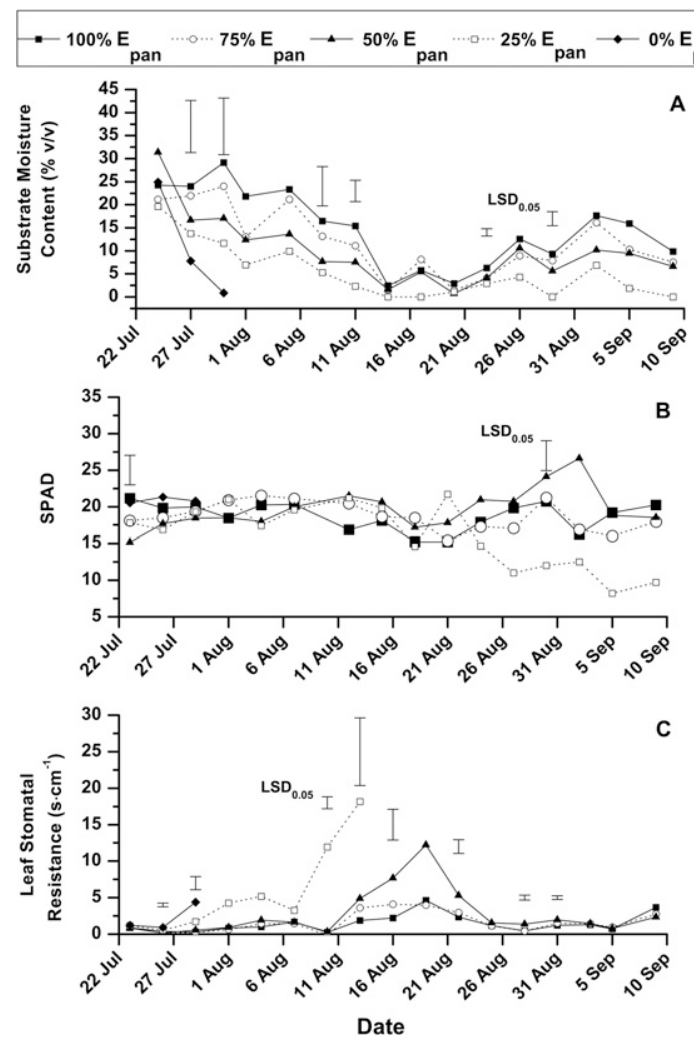

Fig. 5. (A) Substrate moisture content (\% v/v), (B) soil plant analysis development (SPAD) values, and (C) leaf stomatal resistance $\left(\mathrm{s} \cdot \mathrm{cm}^{-1}\right)$ for Melissa officinalis under different irrigations regimens $[100 \%$, $75 \%, 50 \%, 25 \%$, and $0 \%$ of daily pan evaporation $\left.\left(\mathrm{E}_{\mathrm{pan}}\right)\right]$. Bars represent Fisher's least significant difference (LSD) at $P<0.05$. 
every 5 or $7 \mathrm{~d}$ (Papafotiou et al., 2013). As in the case of Greek horehound, nonirrigated plants survived for $20 \mathrm{~d}$ indicating a good drought tolerance plant response.

SPAD values during the water-stress period had minimal differences and, in those cases, they were increased for the irrigation treatments of $50 \%, 75 \%$, and $100 \% \mathrm{E}_{\text {pan }}$ except for a single date when $25 \% \mathrm{E}_{\mathrm{pan}}$ provided increased SPAD value (Fig. 4B). SPAD values for all treatments were gradually reduced as the water-stress study progressed, indicating a reduction in chlorophyll concentration.

Differences between irrigation treatments with regard to leaf stomatal resistance occurred only at the initiation of the study when the nonirrigated plants reached $12.5 \mathrm{~s} \cdot \mathrm{cm}^{-1}$ (Fig. 4C). All other irrigation treatments provided similar low values. From these results, it was concluded that, since it keeps its stomata open, helichrysum is capable of transpiring even at minimum levels of substrate moisture. It is likely that another mechanism, either metabolic or morphological, is mainly responsible for the increased substrate moisture-stress tolerance exhibited by helichrysum.

Melissa officinalis. In the case of lemon balm, the substrate moisture content presented more pronounced differences between different irrigation regimens in comparison with the other plants (Fig. 5A). The highirrigation regimens $\left(100 \%\right.$ and $\left.75 \% \mathrm{E}_{\mathrm{pan}}\right)$ provided increased substrate moisture content, while irrigation at $50 \%$ and $25 \% \mathrm{E}_{\text {pan }}$ provided lower moisture content. Moreover, the substrates of the nonirrigated plots lost their moisture content extremely fast, as indicated by the abrupt decline of moisture content to $\approx 1 \%$, which resulted in the loss of all nonirrigated plants within $7 \mathrm{~d}$ after the initiation of the water-stress treatments. All the above indicate that lemon balm has increased transpiration and, thus, it is expected to be a less substrate moisture-stress tolerant species.

Differences in SPAD values between irrigation treatments were minimal until 26 Aug. 2013, when the $25 \% \mathrm{E}_{\text {pan }}$ treatment reduced its SPAD values compared with the $50 \%, 75 \%$, and $100 \% \mathrm{E}_{\mathrm{pan}}$ treatments, indicating a severe reduction of plant chlorophyll content. Munné-Bosch and Alegre (2000) have also reported a decrease in chlorophyll content in lemon balm plants growing under drought conditions. Our findings contradict those of Ozturk et al. (2004) who reported that lemon balm plants proved to be drought tolerant when growing in lysimeters (of $62-\mathrm{cm}$ diameter and $22-\mathrm{cm}$ depth) filled with a sandy loam soil. In our study, substrate depth was only $8 \mathrm{~cm}$ in an effort to simulate a shallow adaptive green roof system. In the latter cases, plants that have a drought-avoidance mechanism, such as the development of deeper root systems, are handicapped on account of the limited substrate depth. In addition, lemon balm has leaves that are thin and not covered with hairs. It was noticed macroscopically that, lemon balm leaves turn yellow and brown very fast even from the initial stages of waterstress imposition.

The nonirrigated plants increased their leaf stomatal resistance and died out when it reached $4.8 \mathrm{~s} \cdot \mathrm{cm}^{-1}$ (Fig. 5C). The $25 \% \mathrm{E}_{\mathrm{pan}}$ treatment plants also died out $19 \mathrm{~d}$ after the initiation of the water-stress treatments, reaching a leaf stomatal resistance value of $17.5 \mathrm{~s} \cdot \mathrm{cm}^{-1}$. Munné-Bosch and Alegre (1999) reported that lemon balm plants subjected to water-stress conditions decreased their stomatal conductance by $50 \%$ compared with well-watered plants. In our case, we also observed a similar increase in stomatal resistance (Fig. 5C). However, this increase was brief since the plants died soon after they reached a threshold value of $\approx 20 \mathrm{~s} \cdot \mathrm{cm}^{-1}$.

Our results are in contrast to those reported by Ozturk et al. (2004), who found that $M$. officinalis plants were resistant to mild water-stress conditions. More specifically, they found that the dry weight decrease under deficit irrigation conditions (irrigation at $0 \%, 12.5 \%, 25 \%, 37.5 \%$, and $50 \%$ of normal irrigation based on lysimeter moistureholding capacity) was not significant up to the level of $25 \%$ of deficit irrigation. From our study, it was determined that an irrigation of at least $50 \%$ of daily $\mathrm{E}_{\mathrm{pan}}$ is required for sustainable growth of lemon balm on shallow green roof systems.

Munné-Bosch and Alegre (1999) found a large decrease of xylematic water potential between irrigated and nonirrigated lemon balm plants. However, water potential of the water-stressed plants remained relatively constant for 2 weeks due to the significant reduction of leaf stomatal aperture. In our case, the nonirrigated plants were not able to survive for 2 weeks which was expected due to the shallow depth of the green roof substrate layer.

Rosmarinus officinalis. The slope of the moisture curve reduction of the nonirrigated plants was similar to that of helichrysum and Greek horehound and less steep than that of lemon balm and Greek sage, indicating that rosemary did not consume water very rapidly under drought conditions (Fig. 6A). At the initiation and toward the end of the waterstress period, the $25 \% \mathrm{E}_{\text {pan }}$ irrigation regimen had a lower substrate moisture content compared with all higher irrigation regimens. The $100 \%, 75 \%$, and $50 \% \mathrm{E}_{\text {pan }}$ irrigation regimens provided similar substrate moisture content throughout the study.

SPAD values were reduced for a single date in the plants that were nonirrigated (Fig. 6B). In general, SPAD values remained

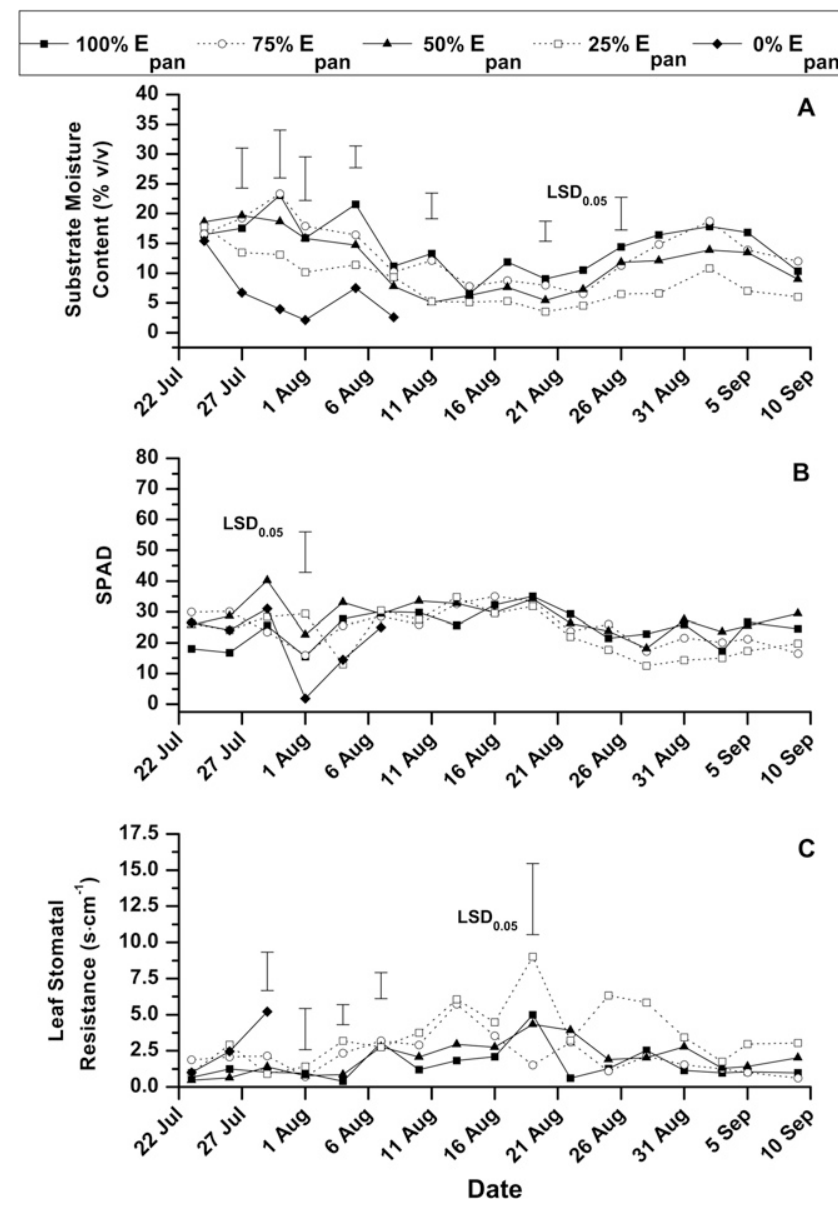

Fig. 6. (A) Substrate moisture content (\% v/v), (B) soil plant analysis development (SPAD) values, and (C) leaf stomatal resistance $\left(\mathrm{s} \cdot \mathrm{cm}^{-1}\right)$ for Rosmarinus officinalis under different irrigations regimens $[100 \%$, $75 \%, 50 \%, 25 \%$, and $0 \%$ of daily pan evaporation $\left.\left(\mathrm{E}_{\mathrm{pan}}\right)\right]$. Bars represent Fisher's least significant difference (LSD) at $P<0.05$. 
relatively stable for all treatments during the water-stress period. However, no significant differences between the four irrigation regimens $\left(25 \%, 50 \%, 75 \%\right.$, and $\left.100 \% \mathrm{E}_{\text {pan }}\right)$ were observed throughout the study (Figs. 2 and $6 B)$. Since SPAD is an indicator of the chlorophyll content of the leaves, our results comply with the findings of Munné-Bosch et al. (1999). They reported that, droughtstressed rosemary plants grown in the field reduced their diurnal $\mathrm{CO}_{2}$ assimilation by $80 \%$ even though the maximum efficiency of photosystem II and chlorophyll content were unaffected.

The nonirrigated plants of rosemary increased their leaf stomatal resistance immediately after the imposition of drought stress (Fig. 6C). However, after 29 July 2013 it was not possible to determine leaf stomatal resistance at the nonirrigated plants although the plants did not die out. It is possible that this resulted from the increased stomatal resistance values that exceeded the poremeter detection capacity. For the remaining time of the water-stress period, the $25 \%$ $\mathrm{E}_{\mathrm{pan}}$ irrigation regimen provided a trend of higher leaf stomatal resistance values, suggesting increased water stress for the period of this treatment. In addition, it indicated that stomata closure is one of the main substrate moisture-stress tolerance mechanisms of rosemary for withstanding dry down periods.

Several researchers have reported the ability of rosemary to exhibit osmotic adjustment when grown under water-stress conditions. Sanchez-Blanco et al. (2004) reported that changes in rosemary plants due to deficit irrigation can be considered as a morphological adaptation of the species to water stress, thereby reducing the rate of transpiration and minimizing water consumption. In addition, Nogués and Baker (2000) and Nogués et al. (2001) observed that during severe summer drought, rosemary significantly decreased its photosynthetic rate, probably by means of strong stomata closure. Apart from the morphological adaptations, Munné-Bosch et al. (1999) showed that rosemary is able to successfully withstand prolonged drought by increasing the concentration of a-tocopherol, carnosic acid, and carotenoid concentration in the leaves. The production of these antioxidants prevents the oxidative damage in the plants.

Salvia fruticosa. The substrate moisture in plots with nonirrigated plants was reduced abruptly, as illustrated by the curve slope (Fig. 7A), indicating fast water consumption by the plants. From the initiation of the waterstress period until 14 Aug. 2013, there was a clear separation between the different irrigation regimens into two groups. More specifically, the $25 \%$ and $50 \% \mathrm{E}_{\text {pan }}$ regimens exhibited lower moisture content, while the $75 \%$ and $100 \% \quad \mathrm{E}_{\mathrm{pan}}$ regimens exhibited higher moisture content. From then on and until the end of the water-stress period, $100 \%$ $\mathrm{E}_{\text {pan }}$ had increased substrate moisture content compared with the other irrigation regimen treatments.
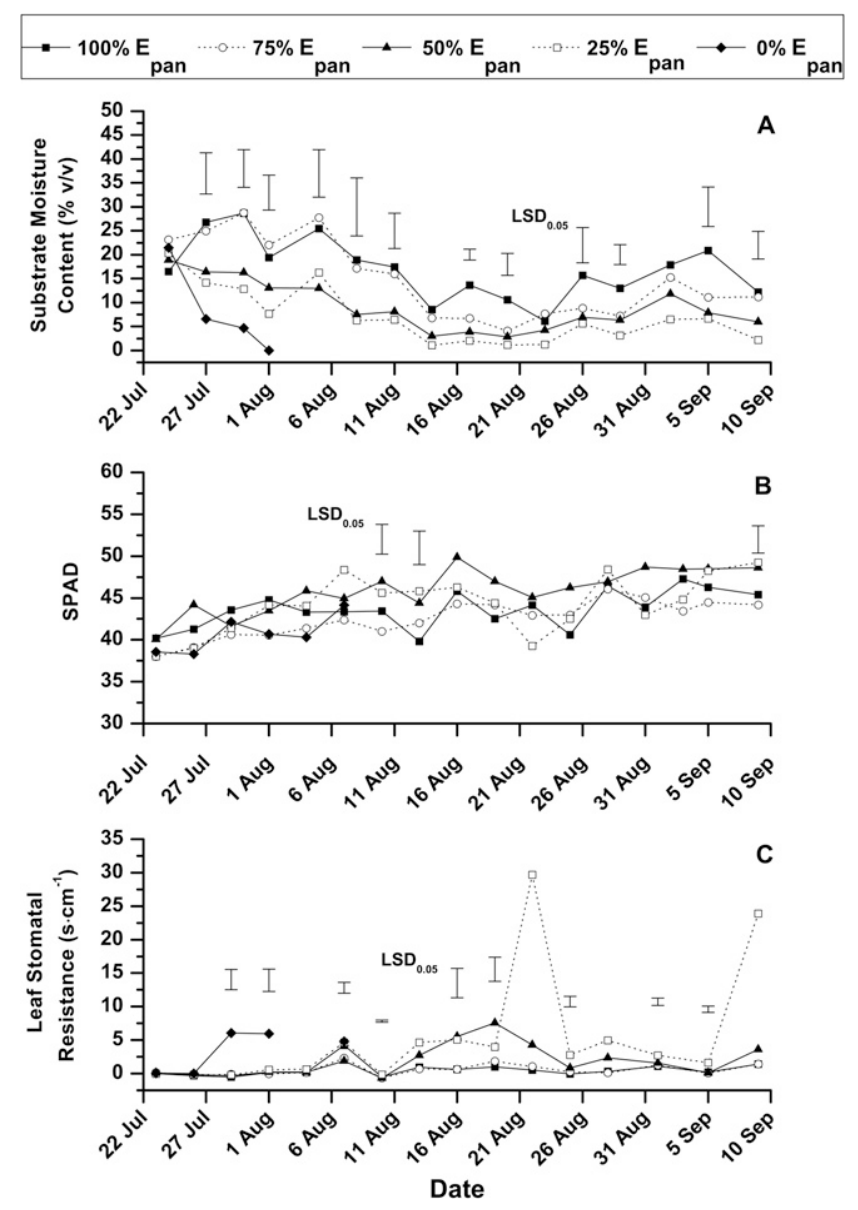

Fig. 7. (A) Substrate moisture content (\% v/v), (B) soil plant analysis development (SPAD) values, and (C) leaf stomatal resistance $\left(\mathrm{s} \cdot \mathrm{cm}^{-1}\right)$ for Salvia fruticosa under different irrigations regimens $[100 \%, 75 \%$, $50 \%, 25 \%$, and $0 \%$ of daily pan evaporation $\left.\left(\mathrm{E}_{\mathrm{pan}}\right)\right]$. Bars represent Fisher's least significant difference (LSD) at $P<0.05$.

The nonirrigated plants of Greek sage died out $10( \pm 2) \mathrm{d}$ after the imposition of drought stress. Bettaieb et al. (2009) reported that 2 weeks after the imposition of water stress, $S$. officinalis plants exhibited a negative effect on their morphological characteristics which became more pronounced as water stress progressed. They observed that severely water-deprived plants produced thinner stems with fewer and more dehydrated leaves compared with other plants that were irrigated at higher irrigation regimens. In our case, it was observed that Greek sage plants under water-stress conditions reduced the size of the leaves by twirling. In addition, the whole leaf area was reduced by turning the leaves yellow and shedding them (Fig. 2).

The SPAD values of Greek sage increased as water stress progressed (Fig. 7B). This could have been caused by an increase in cell solute concentration. Differences in SPAD values were minimal and, in those cases, plants irrigated at $25 \%$ and $50 \% \mathrm{E}_{\mathrm{pan}}$ had higher SPAD values compared with the $75 \%$ and $100 \% \mathrm{E}_{\mathrm{pan}}$ irrigation regimens.

At the initiation of the water-stress period, the nonirrigated plants had increased leaf stomatal resistance (Fig. 7C). After they died out, the $25 \%$ and $50 \% \mathrm{E}_{\mathrm{pan}}$ irrigation regimens had increased leaf stomatal resistance, which illustrates their higher stress compared with the $75 \%$ and $100 \%$ irrigation regimens. Raimondo et al. (2015) installed S. officinalis plants in experimental modules on a green roof and remarked that plants subjected to water stress reduced their leaf water potential close to the point of turgor loss through osmotic adjustment to reduce water consumption and to survive throughout the dry down period.

\section{Conclusions}

A specific irrigation threshold was determined to secure sustainable growth of each plant species under adaptive green roof conditions. More specifically, sustainable growth of Greek horehound, helichrysum, and rosemary can be achieved when they are irrigated at $25 \% \mathrm{E}_{\text {pan }}$. By contrast, lemon balm and Greek sage demand an irrigation regimen of at least $50 \% \mathrm{E}_{\mathrm{pan}}$ to secure sustainable growth on shallow-depth green roof systems. It was also established that extreme caution is necessary in relation to the irrigation frequency of the latter two species, given that their plants died within 7-10 d of withholding irrigation treatments. 


\section{Literature Cited}

Akbari, H., M. Pomerrantz, and H. Taha. 2001. Cool surfaces and shade trees to reduce energy use and improve air quality in urban areas. Sol. Energy 70:295-310.

Benvenuti, S. and D. Bacci. 2010. Initial agronomic performances of Mediterranean xerophytes in simulated dry green roofs. Urban Ecosyst. 13:349-363.

Bettaieb, I., N. Zakhama, W. Aidi Wannes, M.E. Kchouk, and B. Marzouk. 2009. Water deficit effects on Salvia officinalis fatty acids and essential oils composition. Sci. Hort. 120:271-275.

Bousselot, J.M., J.E. Klett, and R.D. Koski. 2011. Moisture content of extensive green roof substrate and growth response of 15 temperate plant species during dry down. HortScience 46:518-522.

Czemiel Berndtsson, J. 2010. Green roof performance towards management of runoff water quantity and quality: A review. Ecol. Eng. $36: 351-360$.

Dimopoulos, P., T. Raus, E. Bergmeier, T. Constantinidis, G. Iatrou, S. Kokkini, A. Strid, and D. Tzanoudakis. 2013. Vascular plants of Greece: An annotated checklist. Botanischer Garten und Botanisches Museum (eds.). BerlinDahlem (Berlin) and Hellenic Botanical Society (Athens).

Ferguson, B.K. 1998. Introduction to stormwater: Concept, purpose, design. Wiley, New York.

Fioretti, R., A. Palla, L.G. Lanza, and P. Principi. 2010. Green roof energy and water related performance in the Mediterranean climate. Build Environ. 45:1890-1904.

Forschungsgesellschaft Landschaftsentwicklung Landschaftsbau (FLL). 2008. Guidelines for the planning, construction and maintenance of green roofing: Green roofing guideline. Bonn, Germany.

Getter, K.L., D.B. Rowe, G.P. Robertson, B.M. Cregg, and J.A. Andresen. 2009. Carbon sequestration potential of extensive green roofs. Environ. Sci. Technol. 43:7564-7570.

Getter, L.K. and D.B. Rowe. 2006. The role of extensive green roofs in sustainable development. HortScience 41:1276-1285.

Heywood, V.H. and I.B.K. Richardson. 1990 Ballota acetabulosa Benth. In: T.G. Tunin, V.H. Heywood, N.A. Burges, D.M. Moore, D.H. Valentine, S.M. Walters, and D.A. Webb (eds.). Flora europaea. Vol. 3. Cambridge University Press, Cambridge, UK.

Kargas, G., N. Ntoulas, and P.A. Nektarios. 2013. Soil texture and salinity effects on calibration of TDR300 dielectric moisture sensor. Soil Res. 51:330-340.

Kotsiris, G., A. Androutsopoulos, E. Polychroni, and P.A. Nektarios. 2012a. Dynamic U-value estimation and energy simulation for green roofs. Energy Build. 45:240-249.

Kotsiris, G., P.A. Nektarios, and A.T. Paraskevopoulou. 2012b. Lavandula angustifolia growth and physiology is affected by substrate type and depth when grown under Mediterranean semi-intensive green roof conditions. HortScience 47:311-317.

Kotsiris, G., P.A. Nektarios, N. Ntoulas, and G. Kargas. 2013. An adaptive approach to intensive roofs in the Mediterranean climatic region. Urban For. Urban Green. 12:380-392.

Kumar, R. and S.C. Kaushik. 2005. Performance evaluation of green roof and shading for thermal protection of buildings. Build. Environ. 40:1505-1511.

Loh, F.C.W., J.C. Grabosky, and N.L. Bassuk. 2002. Using SPAD 502 meter to assess chlorophyll and nitrogen content of benjamin fig and cottonwood leaves. HortTechnology 12: 682-686.

Munné-Bosch, S. and L. Alegre. 1999. Role of dew on the recovery of water-stressed Melissa officinalis L. plants. J. Plant Physiol. 154: 759-766.

Munné-Bosch, S. and L. Alegre. 2000. Changes in carotenoids, tocopherols and diterpenes during drought and recovery, and the biological significance of chlorophyll loss in Rosmarinus officinalis plants. Planta 210:925-931.

Munné-Bosch, S., K. Schwarz, and L. Alegre. 1999. Enhanced formation of $\alpha$-tocopherol and highly oxidized abietane diterpenes in waterstressed rosemary plants. Plant Physiol. 121: 1047-1052.

Nektarios, P.A., I. Amountzias, I. Kokkinou, and N. Ntoulas. 2011. Green roof substrate type and depth affect the growth of the native species Dianthus fruticosus under reduced irrigation regimens. HortScience 46:1208-1216.

Nektarios, P.A., N. Ntoulas, E. Nydrioti, I. Kokkinou, E.-M. Bali, and I. Amountzias. 2015. Drought stress response of Sedum sediforme grown in extensive green roof systems with different substrate types and depths. Sci. Hort. 181:52-61.

Nogués, S. and N.R. Baker. 2000. Effects of drought on photosynthesis in Mediterranean plants grown under enhanced UV-B radiation. J. Expt. Bot. 51:1309-1317.

Nogués, S., S. Munné-Bosch, J. Casadesús, M. López-Carbonell, and L. Alegre. 2001. Daily time course of whole-shoot gas exchange rates in two drought exposed Mediterranean shrubs. Tree Physiol. 21:51-58.

Ntoulas, N. and P.A. Nektarios. 2015. Paspalum vaginatum drought tolerance and recovery in adaptive extensive green roof systems. Ecol. Eng. 82:189-200.

Ntoulas, N., P.A. Nektarios, E. Charalambous, and A. Psaroulis. 2013a. Zoysia matrella cover rate and drought tolerance in adaptive extensive green roof system. Urban For. Urban Green. 12:522-531

Ntoulas, N., P.A. Nektarios, and E. Nydrioti. 2013b. Performance of Zoysia matrella in shallow green roof substrates under moisture deficit conditions. HortScience 48:929-937.

Ntoulas, N., P.A. Nektarios, K. Spaneas, and N. Kadoglou. 2012. Semi-extensive green roof substrate type and depth effects on Zoysia matrella 'Zeon' growth and drought tolerance under different irrigation regimens. Acta Agr. Scand. Sect. B Soil Plant Sci. 62:165-173.

Oberndorfer, E., J. Lundholm, B. Bass, R.R. Coffman, H. Doshi, N. Dunnett, S. Gaffin, M. Köhler, K.K.Y. Liu, and B. Rowe. 2007. Green roofs as urban ecosystems: Ecological structures, functions, and services. Bioscience 57:823-833.

Ozturk, A., A. Unlukara, A. Ipek, and B. Gurbuz. 2004. Effects of salt stress and water deficit on plant growth and essential oil content of lemon balm (Melissa officinalis L.). Pak. J. Bot. 36: 787-792.

Papafotiou, M., N. Pergialioti, L. Tassoula, I. Massas, and G. Kargas. 2013. Growth of native aromatic xerophytes in an extensive Mediterranean green roof as affected by substrate type and depth and irrigation frequency. HortScience 48:1327-1333.

Paraskevopoulou, A., I. Mitsios, I. Fragakis, P.A. Nektarios, N. Ntoulas, P. Londra, and M. Papafotiou. 2015. The growth of Arthrocnemum macrostachyum and Halimione portulacoides in an extensive green roof system under two watering regimes. Agr. Agricultural Sci. Procedia 4:242-249.

Parkhurst, D.F. and O.L. Loucks. 1972. Optimal leaf size in relation to environment. J. Ecol. 60:505-537.

Raimondo, F., P. Trifilo, M.A.L. Gullo, S. Andri, T. Savi, and A. Nardini. 2015. Plant performance on Mediterranean green roofs: Interaction of species-specific hydraulic strategies and substrate water relations. AoB Plants 7:Plv007.

Rowe, D.B. 2011. Green roofs as a means of pollution abatement. Environ. Pollut. 159:2100-2110.

Sanchez-Blanco, M.J., F. Ferrandez, M.A. Morales, A. Morte, and J. Alarcon. 2004. Variations in water status, gas exchange, and growth in Rosmarinus officinalis plants infected with Glomus deserticola under drought conditions. J. Plant Physiol. 161:675-682.

Shields, L.M. 1950. Leaf xeromorphy as related to physiological and structural influences. Bot. Rev. 16:399-447.

Simmons, M.T., B. Gardiner, S. Windhager, and J. Tinsley. 2008. Green roofs are not created equal: The hydrologic and thermal performance of six different extensive green roofs and reflective and non-reflective roofs in a subtropical climate. Urban Ecosyst. 11:339-348.

Tassoula, L., M. Papafotiou, G. Liakopoulos, and G. Kargas. 2015. Growth of the native xerophyte Convolvulus cneorum L. on an extensive Mediterranean green roof under different substrate types and irrigation regimens. HortScience 50:1118-1124.

VanWoert, N.D., D.B. Rowe, J.A. Andresen, C.L. Rugh, and L. Xiao. 2005. Watering regime and green roof substrate design affect Sedum plant growth. HortScience 40:659-664. 